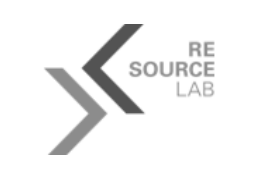

PSCM

Postprint

\title{
How to evaluate raw material supply risks - an overview
}

\author{
Benjamin Achzet ${ }^{\mathrm{a}, \mathrm{b}}$, Christoph Helbig ${ }^{\mathrm{b}}$ \\ *Address correspondence to: christoph.helbig@wiwi.uni-augsburg.de \\ ${ }^{a}$ Resource Lab, Institute of Materials Resource Management, University of Augsburg, \\ Universitaetsstr. 16, 86159 Augsburg, Germany \\ ${ }^{b}$ Production \& Supply Chain Management, Institute of Materials Resource Management, University of Augsburg, \\ Universitaetsstr. 16, 86159 Augsburg, Germany
}

Published in: Resources Policy 38 (2013), 435-447. https://doi.org/10.1016/i.resourpol.2013.06.003

\begin{abstract}
Some strategic raw materials do have an extremely unsecure supply situation. Several working groups around the world have made criticality assessments for metallic raw materials to analyze the driving impact factors for this instability. However, the influences on raw material availability are manifold and therefore criticality assessment methods are very heterogeneous. Here we give an overview about the differences and similarities of supply risk evaluation in 15 criticality assessment methods. We take the example of Indium, which has been rated in $60 \%$ of thesecriticality studies, and show which data base is used for supply risk evaluation. Our results show a lack of consensus about which indicators give reliable information for raw material supply risk and how these indicators should be aggregated. We anticipate our essay to be a starting point for more justified indicator selection and weighting in criticality assessments.
\end{abstract}

\section{Keywords}

resources, raw materials, criticality, supply risk, indium, depletion time 


\section{Criticality}

The term 'criticality' was first used in 1939 in context with raw materials. In those days, the American administration decided to build up a stock for 42 raw materials with military relevance. This was enforced by the so called "Critical Material Stockpiling Act" (U.S. National Research Council, 2008). That stockpiling was aiming to ensure independent access to raw materials for a military emergency case. After the end of the Cold War, the geopolitical situation relaxed. Nonetheless, the stockpiling of military relevant raw materials is continued until today. The American Secretary of Defense reports that until year 2015 the stockpiling for manganese, tungsten, beryllium and cobalt shall be increased (Sectretary of Defense, 2011). This expresses that 'criticality' is still a term strongly influenced by national policy. At the same time, the term has found its way into peer-reviewed literature (Graedel, et al., 2011a) (Rosenau-Tornow, et al., 2009). The criticality of raw materials today is no longer limited to national economies and military technologies, though the term still is predominantly used in reports of governments or consulting organizations. Criticality can refer to a global or regional level, to specific technologies or whole industry branches. In addition to the strategic importance of raw materials, ecological, political, social, ethical and technical aspects of criticality can be considered (Kristof \& Hennicke, 2010). Criticality today covers an integral and complex resource contemplation, which is displayed in the encountered heterogeneous research field (see Table 1).

\subsection{Target and method}

With consideration of the manifold use of the term criticality, the aims of criticality studies in principle can be categorized into four categories: national level studies, future technology studies, entrepreneurial perspective studies and selected target studies.

We had a look on 15 criticality studies from 2006 until 2011, which are to our best knowledge and according to the Yale University (Erdmann \& Graedel, 2011a) the most important criticality studies with a defined aggregation of criticality indicators. These 15 studies are listed in table 1 together with their respective aims. Additional studies without such an aggregation are not evaluated here. By comparing all these studies, we found a general approach of how criticality is developed.

Table 1: Selected studies for the criticality of raw materials, their targets and the categorization. Category 1 studies evaluate the economic importance of raw materials on a national level. In Category 2 the importance of raw materials for specific branches of future technologies is evaluated. In Category 3 critical raw materials are assessed from an entrepreneurial perspective. In Category 4 raw materials are discussed in detail concerning selected targets such as demand increase of conflict potential.

\begin{tabular}{lll}
\hline Cat. & Study & Aim \\
\hline 1 & Frondel, et al., 2006 & Analysis of critical materials for Germany \\
\cline { 2 - 3 } & U.S. National Research Council, & Analysis of critical minerals for the modern U.S. society \\
\cline { 2 - 3 } & Oakdene Hollins, 2008 & Analysis of critical materials fo the U.K. economy \\
\hline Graedel, et al., 2011a & Method for assessing metal criticality \\
\cline { 2 - 3 } & European Commission, 2010 & Analysis of critical materials for the European Union \\
\cline { 2 - 3 } & Thomason, et al.,2010 & Analysis of potential supply shortfalls for the U.S. in case of war \\
\hline 2 & Department of Energy, 2011 & Identification of critical raw materials for alternative energy technologies
\end{tabular}




\begin{tabular}{lll}
\hline & Moss, et al., 2011 & Identification of critical raw materials for alternative energy technologies \\
\hline 3 & IW Consult, 2009 & Identification of critical raw materials for Bavarian companies \\
\cline { 2 - 3 } & Rosenau-Tornow, et al., 2009 & Identification of long term supply-risks for raw materials \\
\cline { 2 - 2 } & Buchert, et al., 2009 & $\begin{array}{l}\text { Identification of critical raw materials for alternative energy technologies and their } \\
\text { recycling potential }\end{array}$ \\
\hline Erdmann, et al., 2011b & Identification of critical raw materials for German companies \\
\cline { 2 - 3 } & Duclos, et al., 2008 & Identification of critical raw materials for General Electric \\
\hline 4 & Behrendt, et al., 2007 & Measurement of confict increasing potentials of resource extraction \\
\cline { 2 - 3 } & Angerer, et al., 2009 & Identification of growth potentials for selected technologies \\
\hline
\end{tabular}

In the observed criticality studies the first step is a generic selection of indicators, as a starting point to evaluate raw material risks. These risks are principally summarized in supply risks, vulnerabiltity and ecological risks. For any of these risks an individual set of criteria is definded by each criticality study.

In a second step, the criteria are aggregated most frequently by using a weighted average to calculate the final ratings for supply risks, vulnerability and ecological risks. Only a few studies use more sophisticated algorithms for calculation or do not give any concrete information about aggregation.

Finally these corresponding target values are then aggregated either linear, or in a matrix, or 3dimensional in order to get the final criticality value.

To address the different aims of the studies, which we list in Table 1, each individual publication selects and aggregates several criteria. The Yale University already detected that the method and the selection of criteria can have severe impact on the evaluation of resource criticality and calls for giving reason for the selection, evaluation and aggregation of the criteria in future studies (Erdmann \& Graedel, 2011a).

These considerations from the Yale University are raising the question if a standardized methodology for criticality methods is suitable to express the individual risks of every raw material. Until today most criticality assessment methods are based on an average aggregation, which often uses a weighted average. By using such a weighted average or even just single indicators, these studies are assuming that every indicator has the same impact on raw material criticality for every raw material. For supply risk evaluation, only three studies use a different approach by applying the maximum or the multiplication of indicators, or they using indicators in a multi-step selection process (U.S. National Research Council, 2008) (European Commission, 2010a) (Frondel, et al., 2006). In the real world raw material risk patterns are of course highly dynamic and vary from element to element (Achzet, 2012). A criticality method must therefore simplify the real world without giving decision makers the wrong signals.

Cadmium for example has well distributed production spots and capacities; the recycling rate is at the moment as high as $20 \%$, mainly provided by NiCd batteries. Most of the current criticality methods would therefore state: cadmium is not a critical metal.

However the ecological impact of cadmium has effected the supply and demand situation massively with regulations like REACH or RoHS. This review therefore wants to give a better understand of the 
meaningfulness of current criticality methods and the statements which can be derived for decision makers.

In order to do this, we reviewed well known criticality studies and their methodological approach by listing the frequency of used indicators, the awarded weight in each study, its measurement and, if provided, given criticality limits used in the assessments.

As criticality is a manifold value consisting of supply risk, vulnerability and ecological risks, we could not consider all types of indicators. All of the 15 studies evaluated the target value supply risk. We therefore focus in the following on those indicators labeled as supply risk indicators by those 15 criticality studies. The frequency of supply risk, vulnerability and ecological risks in the criticality assessments is displayed in table 2 , together with the given target value aggregation and the specific supply risk indicator aggregation.

Table 2: Target values used by each criticality study.

\begin{tabular}{|c|c|c|c|c|c|}
\hline Study & $\begin{array}{l}\text { Supply } \\
\text { Risk }\end{array}$ & Vulnerability & $\begin{array}{l}\text { Ecological } \\
\text { Risk }\end{array}$ & $\begin{array}{l}\text { Target Value } \\
\text { Aggregation }\end{array}$ & $\begin{array}{l}\text { Supply Risk } \\
\text { Aggregation }\end{array}$ \\
\hline Graedel, et al., 2011a & $\checkmark$ & $\checkmark$ & $\checkmark$ & vector length & weighted average \\
\hline European Commission, 2010a & $\checkmark$ & $\checkmark$ & $\checkmark$ & matrix & multiplicative \\
\hline $\begin{array}{l}\text { U.S. National Research } \\
\text { Council, } 2008\end{array}$ & $\checkmark$ & $\checkmark$ & partially & matrix & maximum \\
\hline Erdmann, et al., 2011b & $\checkmark$ & $\checkmark$ & partially & matrix & weighted average \\
\hline Frondel, et al., 2006 & $\checkmark$ & $x$ & partially & only 1 target value & selective \\
\hline Department of Energy, 2011 & $\checkmark$ & $\checkmark$ & $x$ & matrix & weighted average \\
\hline Duclos, et al., 2008 & $\checkmark$ & $\checkmark$ & 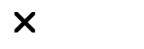 & matrix & average \\
\hline Thomason, et al., 2010 & $\checkmark$ & $x$ & $x$ & only 1 target value & only 1 indicator \\
\hline IW Consult, 2009 & $\checkmark$ & $x$ & 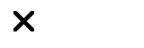 & only 1 target value & weighted average \\
\hline Oakdene Hollins, 2008 & $\checkmark$ & $x$ & $x$ & only 1 target value & average \\
\hline Behrendt, et al., 2007 & $\checkmark$ & $\mathbf{x}$ & 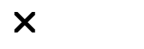 & only 1 target value & average \\
\hline Buchert, et al., 2009 & $\checkmark$ & $\mathbf{x}$ & 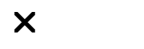 & selective* & average \\
\hline Rosenau-Tornow, et al., 2009 & $\checkmark$ & $\mathbf{x}$ & $\mathbf{x}$ & only 1 target value & $\begin{array}{l}\text { only partial } \\
\text { aggregation }\end{array}$ \\
\hline Moss, et al., 2011 & $\checkmark$ & $\mathbf{x}$ & $\mathbf{x}$ & only 1 target value & weighted average \\
\hline Angerer, et al., 2009 & $\checkmark$ & $x$ & $x$ & only 1 target value & only 1 indicator \\
\hline
\end{tabular}

*: Buchert, et al., additionally uses Recycling Restrictions and Demand Growth as target values

\subsection{Supply Risk Indicators}

Concerning the target value Supply Risk, a total of 20 indicators were identified, which were used in different frequency by the examined studies for evaluation of resource availability. Table 3 shows the frequency, the unit and the data base of each supply risk indicator. 
Table 3: Number, frequency, unit and data base of the indicators for evaluation of supply risks in the selected studies.

\begin{tabular}{|c|c|c|c|}
\hline Indicator & Frequency & Unit & Data base \\
\hline Country Concentration & 12 & {$[\%], \mathrm{HHI}$} & USGS, Raw Materials Group \\
\hline Country Risk & 10 & Index, qualitative & Expert Assessment \\
\hline Depletion Time & 9 & [years] & $\begin{array}{l}\text { USGS, Roskill Information Servies, Raw } \\
\text { Materials Group }\end{array}$ \\
\hline By-Product Dependency & 7 & [\%] & Raw Materials Group \\
\hline $\begin{array}{l}\text { Company Concentration in Mining } \\
\text { Corporations }\end{array}$ & 5 & [\%] & Raw Materials Group \\
\hline Demand Growth & 5 & qualitative, ratio & $\begin{array}{l}\text { European Commission (2010b), USGS, } \\
\text { Projections }\end{array}$ \\
\hline Recycling / Recycling Potential & 3 & [tons] & USGS, Graedel et al. (2011b) \\
\hline Substitutability & 3 & qualitative & $\begin{array}{l}\text { Expert Assessment, European Commission } \\
\text { (2010b) }\end{array}$ \\
\hline Import Dependence & 3 & ratio, net value & $\begin{array}{l}\text { USGS, Proprietary information, Company } \\
\text { Questionnaire }\end{array}$ \\
\hline Commodity Prices & 2 & $\begin{array}{l}\text { [volatility], } \\
{[\mathrm{USD} / \mathrm{kg}]}\end{array}$ & USGS \\
\hline Exploration Degree & 1 & [EUR] & Mining Journals \\
\hline Production Costs in Extraction & 1 & [EUR] & Mining Journals \\
\hline Stockkeeping & 1 & [\%] & USGS \\
\hline Market Balance & 1 & [tonnes] & USGS \\
\hline Mine/Refinery Capacity & 1 & [\%] & Raw Materials Group \\
\hline Future Market Capacity & 1 & [\%] & Raw Materials Group \\
\hline Investment in Mining & 1 & [US\$/tonne] & Raw Materials Group \\
\hline Climate Change Vulnerability & 1 & qualitative & WBGU \\
\hline Temporary Scarcity & 1 & $n / a$ & $n / a$ \\
\hline Risk of Strategic Use & 1 & qualitative & Expert Assessment \\
\hline Abundance in Earth's Crust & 1 & [ppm] & USGS \\
\hline
\end{tabular}

Among the indicators, Country Risk, Country Production Concentration, Static Reach and the ByProduct Dependency were considered by the studies the most. As more than half of the studies used these indicators, it can be assumed that these supply risks indicators have particularly high relevance for supply risk. By-Product Dependency, Company Concentration of Mining and Demand Growth estimations were used by at least one third of the studies, they are of medium relevance. Recyclability, Substitutability, the Import Dependence and Commodity Prices were used by a few supply risk assessments. All other indicators were only used by single studies, making comparisons of their usage impossible. 


\subsubsection{Country Concentration}

In most of the studies the indicator Country Concentration of either production or reserves was used for evaluating supply risks. For measuring the concentration most studies apply either the sum of the one to three largest producer or reserve countries or the Herfindahl-Hirschman Index (HHI). Only one study uses the number of producing countries which combine at least $50 \%$ of the world annual production as an indicator (Moss, et al., 2011). In two cases the assessment for country concentration was combined with the assessment of country risk, i.e. using a country risk weighted Herfindal-Hirschman Index concentration measurement (European Commission, 2010a).

Table 4: Studies using the country-specific production capacities as supply risk indicator and its measurement. The table also shows the limit for classifying an indicator 'critical' and the weight in percent within the aggregation of supply risks evaluation.

\begin{tabular}{|c|c|c|c|}
\hline Criterion & Weight & Measurement & Limit \\
\hline \multirow[t]{6}{*}{$\begin{array}{l}\text { Country } \\
\text { Concentration in } \\
\text { production }\end{array}$} & $\begin{array}{l}\text { 16.7\% “medium-term” } \\
\text { (Graedel, et al., 2011a) } \\
\text { n/a (Rosenau-Tornow, } \\
\text { et al., 2009) } \\
\text { algorithm (Frondel, et } \\
\text { al., 2006) }\end{array}$ & Herfindahl-Hirschman Index & $\begin{array}{l}0.15 \text { - critical } \\
\text { (Frondel, et al., 2006) } \\
0.20 \text { - critical } \\
\text { (Rosenau-Tornow, et al., } \\
2009 \text { ) }\end{array}$ \\
\hline & n/a (Moss, et al., 2011) & $\begin{array}{l}\text { Number of producing countries, } \\
\text { combining } 50 \% \text { of world annual } \\
\text { production }\end{array}$ & $n / a$ \\
\hline & $\begin{array}{l}25 \% \text { (Buchert, et al., } \\
2009 \text { ) } \\
15 \% \text { (IW Consult, 2009) }\end{array}$ & Top 3 & $\begin{array}{l}90 \% \text { - critical } \\
\text { (Buchert, et al., 2009) }\end{array}$ \\
\hline & $\begin{array}{l}\text { 25\% (Oakdene Hollins, } \\
2008)\end{array}$ & Top 1 & $\begin{array}{l}<33 \% \text { - low criticality, }>67 \% \text { - } \\
\text { high criticality (Oakdene } \\
\text { Hollins, 2008) }\end{array}$ \\
\hline & $\begin{array}{l}\text { 16.7\% (Duclos, et al., } \\
2008)\end{array}$ & $\begin{array}{l}\text { qualitative, together with Country } \\
\text { Risk }\end{array}$ & $\mathrm{n} / \mathrm{a}$ \\
\hline & $\begin{array}{l}\text { algorithm (European } \\
\text { Commission, 2010a) }\end{array}$ & $\begin{array}{l}\text { Country Risk }{ }_{\mathrm{HH}} \text {, together with } \\
\text { Country Risk measurement }\end{array}$ & $\mathrm{n} / \mathrm{a}$ \\
\hline Producer Diversity & $\begin{array}{l}\text { 20\% (Department of } \\
\text { Energy, 2011) }\end{array}$ & $\begin{array}{l}\text { combined with Company } \\
\text { Concentration }\end{array}$ & $\mathrm{n} / \mathrm{a}$ \\
\hline $\begin{array}{l}\text { Country } \\
\text { Concentration in } \\
\text { reserves }\end{array}$ & $\begin{array}{l}\text { 10\% (Erdmann, et al., } \\
2011 b) \\
16.7 \% \text { (Behrendt, et al., } \\
2007 \text { ) }\end{array}$ & Top1/Top2/Тop3 & $\begin{array}{l}>50 \% \text { (Top1) or }>65 \% \text { (Top2) - } \\
\text { critical (Behrendt, et al., } \\
\text { 2007) }\end{array}$ \\
\hline Not considered & tional Research & Thomason, et al., 20 & ngerer, et al., 2009) \\
\hline
\end{tabular}

The $\mathrm{HHI}$ is a standard key figure for measuring concentration in economics and is calculated as the sum of the squares of market share, as described in formula 1.

$$
H H I(a)=\sum_{i=1}^{N}\left(a_{i}{ }^{2}\right)
$$

Formula 1: The Herfindahl-Hirschman Index (HHI) is used for calculating market concentrations. $\mathrm{N}$ is the number of producing countries or companies, $\mathrm{a}_{\mathrm{i}}$ is the share of a country or company of the annual production. The squaring results in high production concentrations weighted higher than within a linear sum. (Bleymüller, et al., 1996) 
A typical example for critical raw materials with high production concentration are the element group of rare earths, molybdenum and tungsten. These are mined in the People's Republic of China with a share between $46 \%$ (molybdenum) and $97 \%$ (rare earths). Political decisions concerning export restrictions or taxes had massive impact on historic price development. For tungsten the price increased by around $350 \%$ within the years 2003 to 2010 (USGS, 2011). For dysprosium the increase was even $5700 \%$ within the same time frame (Asian Metals, 2011). Raw materials with highly concentrated production show tensed supply\&demand situations more often. As part of this analysis it has to be questioned to which extend the mere measurement of production concentration can be a basic indicator for resource availability. The high production concentration rather represents an essential risk factor, for which it was to be considered that critical market situations are caused most of the time by resource policy or different conditions. A high production concentration is sufficient to let these events have a strong impact, but it is not sufficient to cause supply shortages all alone.

In the studies of Erdmann and Behrendt, et al., the country concentration of the reserves, not the resources was used as a supply risk indicator. Behrendt, et al., considered a concentration above $50 \%$ in one country or above $65 \%$ in two countries as critical.

According to guidelines by the U.S. Department of Justice and the Federal Trade Commission, concentrations with an $\mathrm{HHI}$ value below 0.15 are considered to be unconcentrated, between 0.15 and 0.25 to be moderately concentrated and above 0.25 to be highly concentrated (U.S. Department of Justice and the Federal Trade Commission, 2010). Nonetheless, these limits for the concentration of resource producing countries are not universally accepted. In a report of the German Federal Ministry of Economics and Technology from 2006, $\mathrm{HHI}$ values of 0.15 and above are considered critical, while in a publication of the Federal Institute for Geosciences and Natural Resources already concentrations of 0.2 and above are evaluated to be critical (Frondel, et al., 2006) (Rosenau-Tornow, et al., 2009). For the Top-3 concentration of producing countries, a value of $90 \%$ is given as the critical concentration by the United Nations Environment Programme (UNEP) (Buchert, et al., 2009). The influence of country production concentration on the evaluation of supply risks was rated by the consulting company Oakdene Hollins with $25 \%$, the study funded by KfW Bankengruppe only gives it $10 \%$ weight in its study (Oakdene Hollins, 2008) (Erdmann, et al., 2011b).

\subsubsection{Country Risk}

The indicator Country Risk combines the distribution of the producing countries with each country's political risk. This quantification grounds either on the "World Governance Index" made by the World Bank, the "Global Policial Risk Index" (GPRI) by Eurasia Group, the "Policy Potential Index" (PPI) by Fraser Institute or the "Human Development Index" (HDI) by United Nations Development Programme (Kaufmann, et al., 2012) (Eurasia Group, 2012). These indices are often combined with the different measures of production concentration used in the corresponding study. Table 3 shows that country risk was one of the two most used criterions for the evaluation of supply risk, with 10 out of 15 studies applying this indicator in their evaluations. 


$$
\begin{aligned}
& \text { Country Risk }_{H H I}(a)=\sum_{i=1}^{N}\left(\alpha_{i} \cdot a_{i}{ }^{2}\right) \\
& \text { Country Risk }_{N}(a)=\sum_{i=1}^{N}\left(\alpha_{i} \cdot a_{i}\right) \\
& \text { Country Risk }_{T O P 3}(a)=\sum_{i=1}^{3}\left(\alpha_{i} \cdot a_{i}\right)
\end{aligned}
$$

Formula 2: The country risk quantifies the political and partially also the social and regulatory risk of the raw material producing countries. The country risk is measured with a link of concentration of the producing countries (HHI, Top3, N) with the political risk in form of an index $\left(\alpha_{i}\right), \alpha_{i}$ either represents the World Gouvernance Index (WGI), the Policy Potential Index (PPI), Humand Development Index (HDI), or the Political Risk Index (GPRI). $a_{i}$ represents the production share of each country of the annual production. $\mathrm{N}$ is the number of producing countries.

The World Governance Index (WGI) is explicitely used by 7 of the selected studies to rate political risk. The WGI is published by the World Bank and is subdivided into six aspects: 'voice and accountablity', 'political stability', 'governant effectiveness', 'regulatory quality', and 'control of corruption'. Oakdene Hollins and the Yale University only use the aspect Political Stability for the calculation of the country risk (Oakdene Hollins, 2008) (Graedel, et al., 2011a). With the subindex political stability the World Bank displays the probability of a destabilization of the administration by inner or outer influences. The European Commission, the KfW Bankengruppe and the scientific advisory board of the European Commission use the average of all WGI aspects for their calculations (European Commission, 2010a) (Erdmann, et al., 2011b) (Moss, et al., 2011).

The indicator Global Political Risk Index (GPRI) was used only by the Cologne Insitute for Economic Research to evaluate political risks of resource availability. The index aggregates political, social and economic aspects to one global risk index (IW Consult, 2009).

In addition to political risks, the publication of Yale University implements social and regulatory risks by including the Policy Potential Index (PPI) and the Human Development Index (HDI) (Graedel, et al., 2011a). The PPI measures the attractivity of a country for exploration of resources based on an evaluation of taxes, ecological regulation, infrastructure, labour market and socio-economic acceptance. The HDI, however, measures the life expectancy of the population, its education and income (United Nations Development Programme, kein Datum).

The study of Erdmann, et al., also uses a weighting of the individual country risks by import share instead of global production share. For there assessment, the WGI values of the top 3 import countries of the raw material form one indicator while the top 3 production country's WGI values form another. Both are weighted with $10 \%$ in the supply risk assessment. 
Table 5: Studies using country risk as supply risk indicators and its measurement. The table also shows the limit for classifying an indicator 'critical' and the weight in percent within the aggregation of supply risks evaluation.

\begin{tabular}{|c|c|c|c|}
\hline Criterion & Weight & Measure & Limit \\
\hline \multirow[t]{6}{*}{ Country Risk } & $\begin{array}{l}\text { algorithm (European Commission, } \\
\text { 2010a) }\end{array}$ & $\begin{array}{l}\text { Country Risk } \mathrm{HH}_{\mathrm{H}} \text {, together with Country } \\
\text { Concentration }\end{array}$ & $\mathrm{n} / \mathrm{a}$ \\
\hline & $\begin{array}{l}25 \% \text { (Oakdene Hollins, 2008), } \\
16.7 \%+16.7 \%+16.7 \% \text { „medium term“ } \\
\text { (Graedel, et al., 2011a) } \\
\text { n/a (Rosenau-Tornow, et al., 2009) } \\
\text { 12.5\% (IW Consult, 2009) } \\
\text { algorithm (Frondel, et al., 2006) }\end{array}$ & Country Risk ${ }_{N}$ & $\begin{array}{l}>5.5-\text { critical } \\
\text { (Rosenau-Tornow, et } \\
\text { al., 2009) } \\
<0.59 \text { - critical } \\
\text { (Frondel, et al., 2006) } \\
<33 \% \text { percentile - } \\
\text { low criticality, } \\
>67 \% \text { percentile - } \\
\text { high criticality } \\
\text { (Oakdene Hollins, } \\
\text { 2008) }\end{array}$ \\
\hline & $10 \%+10 \%$ (Erdmann, et al., 2011b) & $\begin{array}{l}\text { Country Risk } \text { Top3Prod } \\
\text { Country Risk } \\
\text { Top3Import } \\
\end{array}$ & $\mathrm{n} / \mathrm{a}$ \\
\hline & n/a (Moss, et al., 2011) & $\begin{array}{l}\text { Uses WGI and FSI Index combined with } \\
\text { expert assessment }\end{array}$ & $\mathrm{n} / \mathrm{a}$ \\
\hline & 20\% (Department of Energy, 2010) & $\begin{array}{l}\text { Qualitative („political, regulatory and } \\
\text { social factors“) }\end{array}$ & $\mathrm{n} / \mathrm{a}$ \\
\hline & 16.7\% (Duclos, et al., 2008) & $\begin{array}{l}\text { qualitative, together with Country } \\
\text { Concentration measurement }\end{array}$ & $\mathrm{n} / \mathrm{a}$ \\
\hline $\begin{array}{l}\text { Not } \\
\text { considered }\end{array}$ & \multicolumn{3}{|c|}{$\begin{array}{l}\text { (U.S. National Research Council, 2008), (Thomason, et al., 2010), (Buchert, et al., 2009), (Behrendt, et al., } \\
\text { 2007), (Angerer, et al., 2009) }\end{array}$} \\
\hline
\end{tabular}

Next to these quantitative approaches, the American Department of Energy rates the political and regulatory risks of resources qualitatively (Department of Energy, 2010). A key point for these evaluations is the resource strategy of producing countries, with resource strategies being labeled as national political goals and measures with respect to resources. Thus the main goal of the Chinese resource strategy, for example, is named to be supply security for domestic resource demand and the mitigation of illegal extraction. These aims were consequentially persued and implemented in the past by taxes, export restrictions, a ban of foreign mining operators and a moratorium for new mining licences. This procedure was rated by the DOE as critical (Department of Energy, 2010).

A limit for criticality of the Country Risk is given by the BGR study, which evaluates a country risk of 5.5 and above as critical (on a scale from 0 to 10) (Rosenau-Tornow, et al., 2009). Frondel, et al., rates all countries with a WGI value of 0.59 and below as critical (on a scale from -2.5 to 2.5) (Frondel, et al., 2006). Oakdene Hollins prefers to use relative WGI in its study, diving countries into three divisions. While the average weight of the impact of country risks on supply risk was $14.4 \%$, the highest weight can be found in Oakdene Hollins' study with $25 \%$, while the $\mathrm{KfW}$ weight the country risk only with 10\% (Oakdene Hollins, 2008) (Erdmann, et al., 2011b).

\subsubsection{Depletion Time}

The criterion of Depletion Time of reserves was used by a total of 9 out of the 15 selected studies. For calculation, most studies use the static reach of reserves, which is the quotient of the current annual production and the currently known reserves. 
Most of the considered studies take the definition of the term 'reserves' from the U.S. Geological Survey (USGS). As shown in figure 5 , one possible subdivision of the existing raw materials is a classification into reserves, reserve base and resources. Reserves are deposits which are identified and demonstrated and can be economically extracted as of today. The reserve base additionally includes the share of raw materials which can be extracted marginally economic or subeconomically. The USGS no longer uses the term 'reserve base' in its classification system; instead the terms marginal reserves and demonstrated subeconomic resources have been introduced. This change of terms, however, has not found its way into the observed criticality studies. Resources can be identified or undiscovered, without any economic classification (USGS, 2013). The infrastructure for the extraction of reserves is not necessarily considered within the calculation of reserves by the USGS. Thus even the amount of reserves known as of today is just a hypothetic value.

Table 6: Studies using the depletion time as a supply risk indicator and its measurement. The table also shows the weight in percent within the aggregation of supply risks evaluation.

\begin{tabular}{|c|c|c|c|}
\hline Criterion & Weight & Measure & Limit \\
\hline $\begin{array}{l}\text { Static Reach } \\
\text { Reserves }\end{array}$ & $\begin{array}{l}25 \% \text { (Erdmann, et al., } \\
2011 \text { b) } \\
25 \% \text { (Buchert, et al., 2009) } \\
25 \% \text { (Oakdene Hollins, } \\
2008 \text { ) } \\
\text { 12.5\% (IW Consult, 2009) } \\
\text { n/a (Rosenau-Tornow, et al., } \\
\text { 2009) } \\
\text { algo. (U.S. National } \\
\text { Research Council, 2008) } \\
\text { 16.7\% (Behrendt, et al., } \\
2007 \text { ) }\end{array}$ & $\begin{array}{l}R_{\text {Reserve }} \\
=\frac{\text { Reserve }}{\text { Production }}\end{array}$ & $\begin{array}{l}<25 a-\text { critical } \\
\text { (Behrendt, et al., 2007) }\end{array}$ \\
\hline $\begin{array}{l}\text { Static Reach } \\
\text { Reserve Base }\end{array}$ & $\begin{array}{l}\text { n/a (U.S. National Research } \\
\text { Council, 2008) } \\
\text { 16.7\% (Behrendt, et al., } \\
\text { 2007) }\end{array}$ & $\begin{array}{l}R_{\text {ReserveBase }} \\
=\frac{\text { Reserve base }}{\text { Production }}\end{array}$ & $\begin{array}{l}<50 a-\text { critical } \\
\text { (Behrendt, et al., 2007) }\end{array}$ \\
\hline Dynamic Reach & $\begin{array}{l}\text { 25\% (Oakdene Hollins, } \\
2008 \text { ) }\end{array}$ & $\begin{array}{l}\text { Production trend until } \\
2050\end{array}$ & $\begin{array}{l}\text { Reserves not reached - low criticality, } \\
\text { Reserve base overrun - high criticality } \\
\text { (Oakdene Hollins, 2008) }\end{array}$ \\
\hline Depletion Time & $\begin{array}{l}50 \% \text { "long term" } \\
16.7 \% \text { "short term" } \\
\text { (Graedel, et al., 2011a) }\end{array}$ & See Formula 3 & $\mathrm{n} / \mathrm{a}$ \\
\hline Basic Availability & $\begin{array}{l}\text { 40\% (Department of Energy, } \\
\text { 2010) }\end{array}$ & Qualitative score & $\mathrm{n} / \mathrm{a}$ \\
\hline Not considered & \multicolumn{3}{|c|}{$\begin{array}{l}\text { (Frondel, et al., 2006), (European Commission, 2010a), (Thomason, et al., 2010), (Moss, et al., 2011), } \\
\text { (Duclos, et al., 2008), (Angerer, et al., 2009) }\end{array}$} \\
\hline
\end{tabular}

In addition to the calculation of the classical static reach, only Oakdene Hollins and Yale University pursue other calculation methods. Oakdene Hollins calculates a dynamic reach with the quotient of reserve base and possible production scenarios until 2050 (Oakdene Hollins, 2008). Yale University uses an algorithm to calculate the depletion time (DT). DT represents a dynamic reach, which includes the reserves, the demand trends and possible recycling rates within the calculation (Graedel, et al., 2011a). 


$$
R_{t_{0}}-\sum_{i}\left(\int_{t_{0}}^{t_{F}} \psi(t)_{i}+\tau(t)-\left(\int_{t_{0}}^{t_{F}} \frac{1}{\sqrt{2 \pi}} e^{\frac{-\left(t-t^{-}-\mu_{i}\right)^{2}}{2 \sigma_{i}^{2}}} \psi\left(t^{\prime}\right)_{i} d t^{\prime} \times E O L R R_{i}\right) d t\right)=0
$$

Formula 3: Depletion Time (DT) is defined by the time span $t_{F}-t_{0} \cdot t_{0}$ is today, $t_{F}$ is the future point when the resource is depleted. $\mathbf{t}_{\mathbf{F}}$ is calculated with equation 2 . Here $\psi(t)_{i}$ represents the raw material demand, $\tau(t)$ the material losses from extraction to end product, the expression

$\frac{1}{\sqrt{2 \pi}} e^{\frac{-\left(t-t^{\prime}-\mu_{i}\right)^{2}}{2 \sigma_{i}^{2}}}$ represents the life cycle distribution of a resource, in this case a Normal distribution, this can also be a Weibull of Lognormal distribution, EOL $R R_{i}$ is the end-of-life recycling rate. $R_{t_{0}}$ represents reserves in shortterm assessments and reserve base in long-term assessments.

The static and dynamic reach only give limited insight as both are only theoretical values. The truly extracted amount of resource is a complex function depending on technical, economical and political variables. For example, increasing resource prices can help transforming inprofitable deposits into economically rational extraction areas within very short time. This raises the share of extractable reserves. At the same time, political instabilities in the extraction areas or strict environmental regulations can limit the truly accessible reserves substantially and this has nothing to do with economic reasons. A long-term forecast for resource demand and recycling volumina comes along with extreme insecurities in this dynamic and unpredictable situation (Tilton \& Lagos, 2007). If you look at the development of the static reach of the last 20 years, for most raw materials an almost stable value can be observed. The opening of new mines is directly linked to the increase or at least consolidation of the annual production. This connection is also called "equilibrium line" for raw materials. Exploration efforts lead to a compensation of supply and demand volumina of a resource. Studies thus use sinking static reaches not as an availability indicator, but rather as a signal for higher necessity for stock pile exploration (Sievers, et al., 2011).

The observation of depletion time alone does not allow explicit conclusions about the availability of raw materials. This is why it is not recommended to use the static or dynamic reach for a global evaluation of recources. Rather it makes sense to calculate the lifespans for specific stock piles in order to study the impact on the mid- to long-term supply of a resource.

No specific limits for criticality of the indicator depletion time were given. The depletion time of resources was used in the selected studies with an average of $22.5 \%$. The highest weight can be found in the publication of Yale University with $50 \%$, while the Cologne Institute of Economic Research gave it just a weight of $12.5 \%$ (Graedel, et al., 2011a) (IW Consult, 2009). 


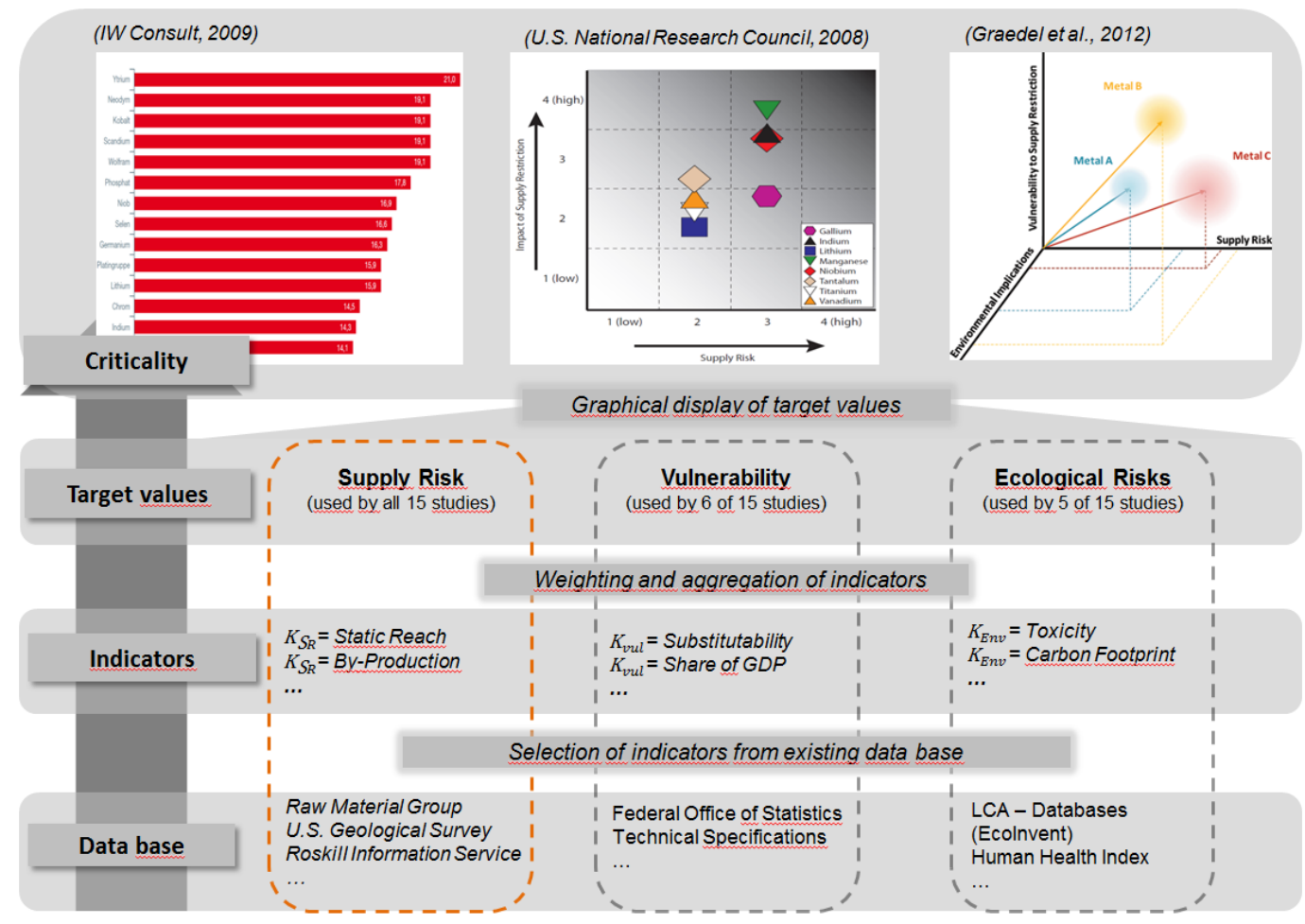

Figure 1: The measurement of resource criticality is being evaluated in the selected studies over the course of multiple levels. The figure shows criticality basically is grounded upon three target values: supply risk, vulnerability and ecological risk (own display).

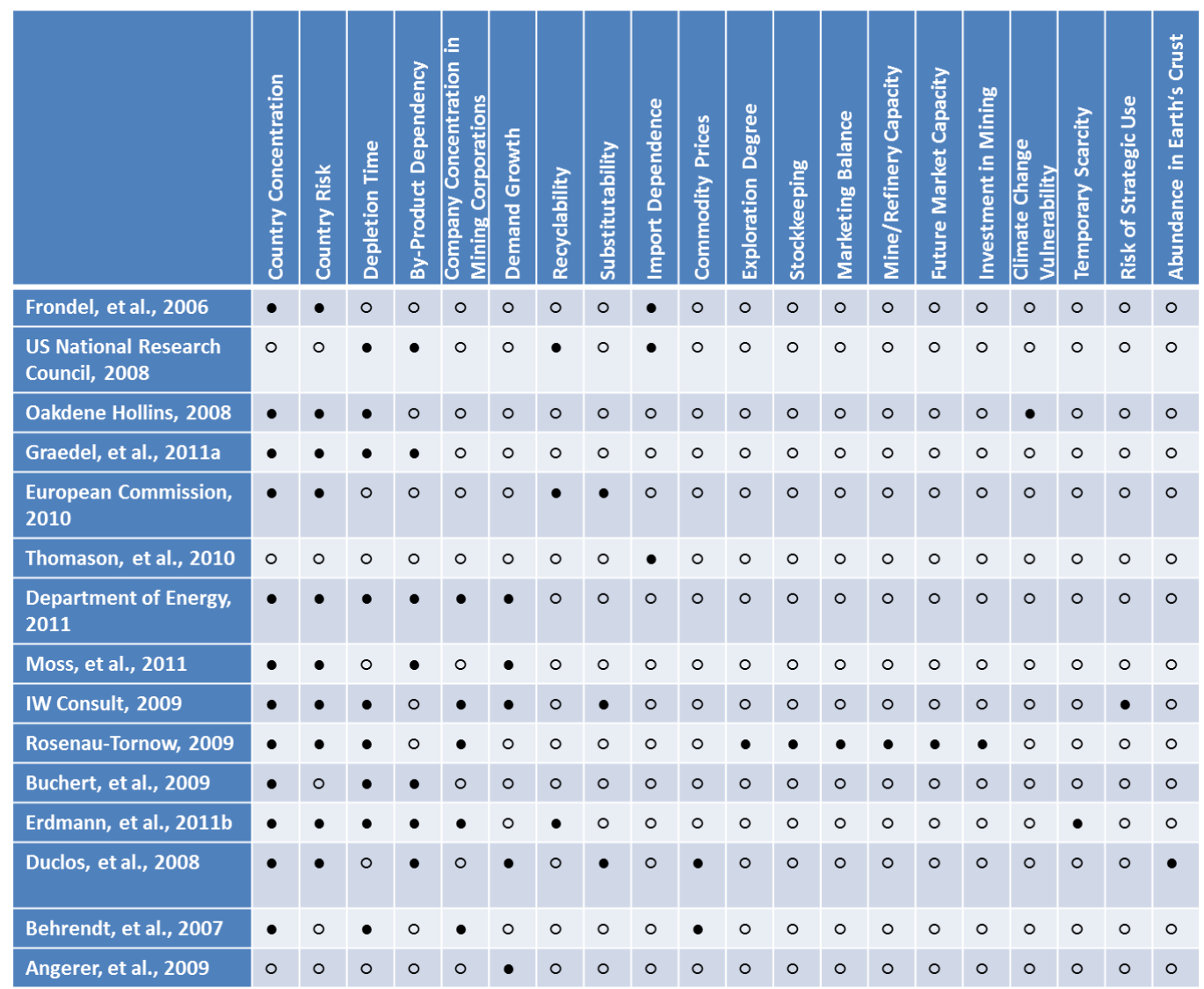

Figure 2: This figure shows in which of the 15 raw material criticality assessments the 20 supply risk indicators were used. Full circles are indicators used by this study, empty circles are indicators not used. Country risk was used in twelve studies. Ten indicators were used only in a single study. Rosenau-Tornow used ten different indicators, while two studies only used a single indicator. 


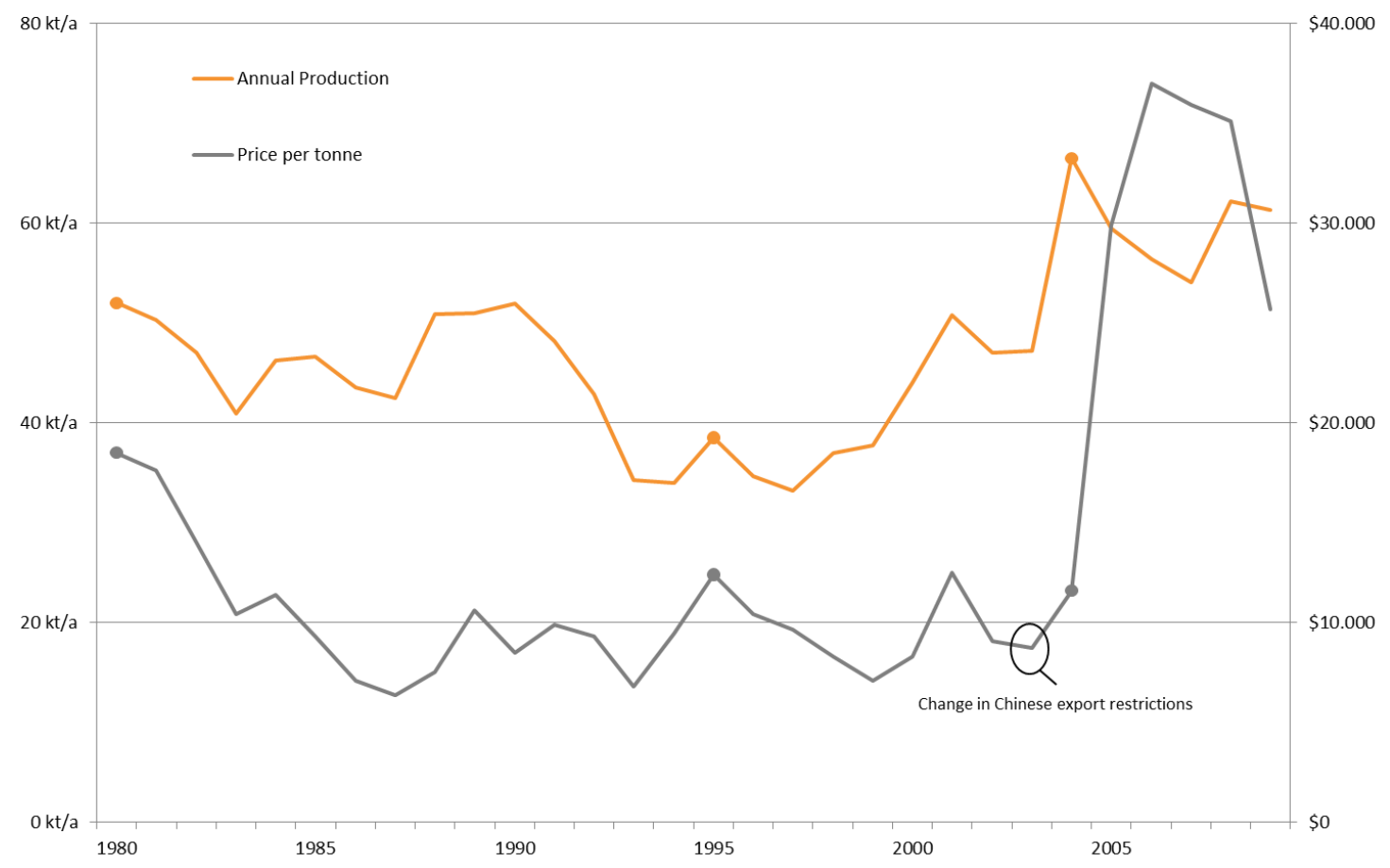

Figure 3: Annual tungsten production and annual average price for tungsten in US-Dollar per ton. A characteristic price increase of over 350\% in year 2007 is marked, which was induced by increased Chinese export duty and export restricitions (USGS, 2011).

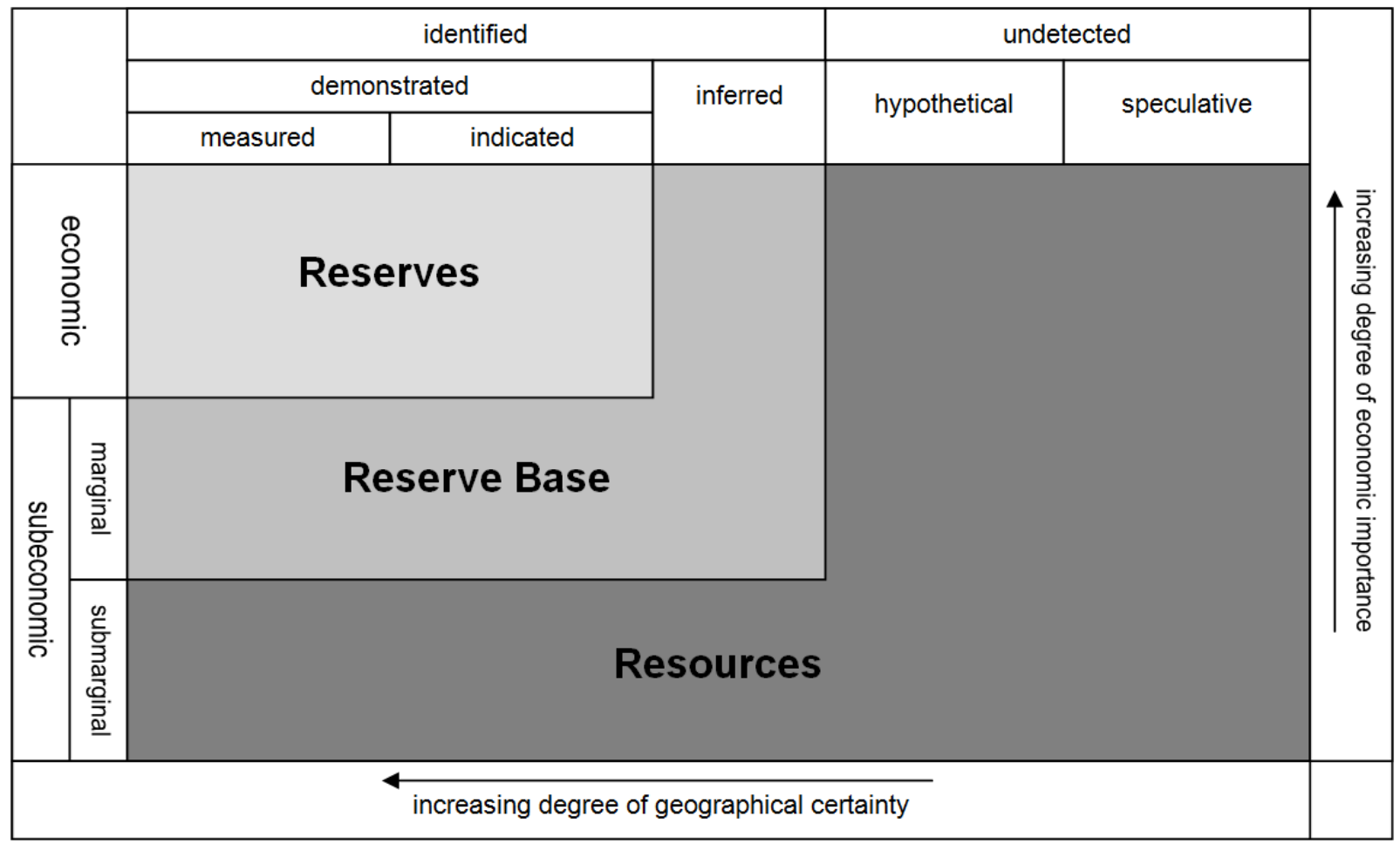

Figure 4: Connection between the terms resources and reserves (USGS, 2006). 


\subsubsection{By-Product Dependency}

The By-Product Dependency is used by 7 of the 15 studies as a criterion for supply risk, which makes up for almost half of all studies. The term 'by-product' describes a mineral or raw material which occurs at the production of a main-metal. Only after a necessary intermediate step the material can be extracted economically. For example, cadmium and indium are typical by-products of zinc extraction and processing. The elasticity of the supply of the by-product is directly limited by the extraction and processing of the main-metals.

In the dissertation of Langhammer it was already shown in 2010, that by-production influences the pricing of a raw material (Langhammer, 2010). The share of by-production is an important indicator for the supply elasticity and because of that also for the temporal availability of a resource.

Table 7: Studies using the by-product dependency as a supply risk indicator and its measurement. The table also shows the limit for classifying an indicator 'critical' and the weight in percent within the aggregation of supply risks evaluation.

\begin{tabular}{|c|c|c|c|}
\hline Criterion & Weight & Measure & Limit \\
\hline By-Product & $50 \%$ "long term" & \multirow{5}{*}{ By-Product $=\frac{\text { By-Production }}{\text { Total Production }}$} & \multirow[t]{5}{*}{$\mathrm{n} / \mathrm{a}$} \\
\hline \multirow[t]{8}{*}{ Dependency } & $16.7 \%$ "short term" & & \\
\hline & (Graedel, et al., 2011a) & & \\
\hline & 10\% (Erdmann, et al., 2011b) & & \\
\hline & algo. (U.S. National Research Council, 2008) & & \\
\hline & 16.7\% (Duclos, et al., 2008) & qualitative & $\mathrm{n} / \mathrm{a}$ \\
\hline & n/a (Moss, et al., 2011) & $\mathrm{n} / \mathrm{a}$ & $\mathrm{n} / \mathrm{a}$ \\
\hline & 25\% (Buchert, et al., 2009) & & \\
\hline & 10\% (Department of Energy, 2010) & & \\
\hline Not considered & \multicolumn{3}{|c|}{$\begin{array}{l}\text { (Frondel, et al., 2006), (Oakdene Hollins, 2008), (European Commission, 2010a), (Thomason, et al., } \\
\text { 2010), (IW Consult, 2009), (Rosenau-Tornow, et al., 2009), (Behrendt, et al., 2007), (Angerer, et al., } \\
\text { 2009) }\end{array}$} \\
\hline
\end{tabular}

No specific limits for criticality of by-product dependency were given. The influence of the indicator on resource availability is weighted in average with $21 \%$. The highest weight can be found in the study of Yale University with $50 \%$ while the DOE only rates the by-product dependency at $10 \%$ (Graedel, et al., 2011a) (Department of Energy, 2010). 


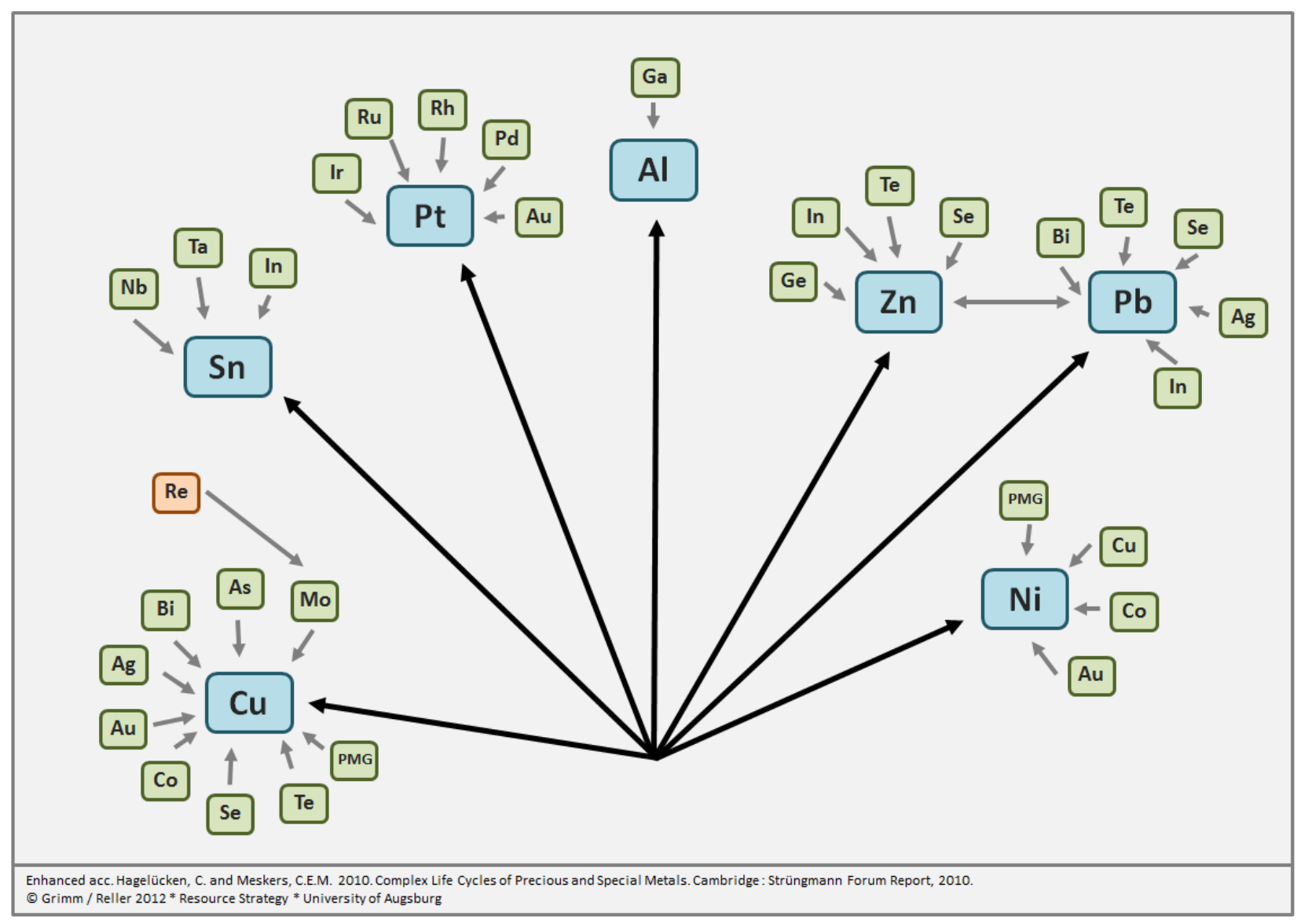

Figure 5: Selected by-products with their respective main-products for primary metal production

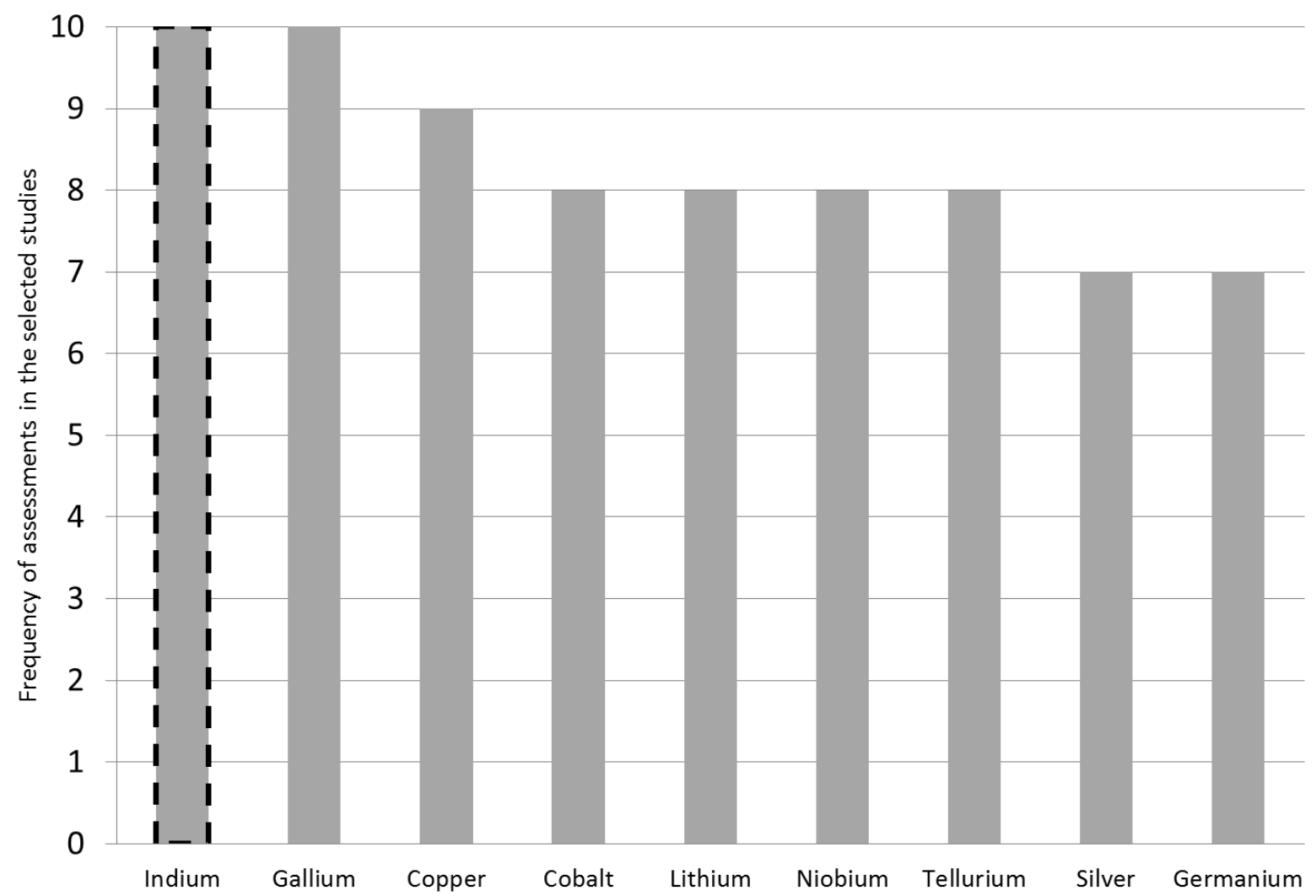

Figure 6: The most frequently examined raw materials in the selected studies. Indium was used in 10 out of 15 studies and thus is the focus of the following data analysis. 


\subsubsection{Concentration of raw material producing companies}

The Company Concentration of raw material producing companies was used as a supply risk indicator by 5 out of 15 selected studies, which is a share of $20 \%$. In most of the studies, only companies which extract raw materials out of ore are considered as raw material producing companies. The BGR additionally includes companies for the processing of raw materials in this evaluation (RosenauTornow, et al., 2009). In one case the evaluation of company concentration is combined with the evaluation of the country concentration (U.S. National Research Council, 2008).

Table 8: Studies using the concentration of raw material producing companies as supply risk indicators and its measurement. The table also shows the limit for classifying an indicator 'critical' and the weight in percent within the aggregation of supply risks evaluation.

\begin{tabular}{|c|c|c|c|}
\hline Criterion & Weight & Measure & Limit \\
\hline \multirow[t]{2}{*}{$\begin{array}{l}\text { Company } \\
\text { concentration }\end{array}$} & $\begin{array}{l}\text { n/a (Rosenau-Tornow, et al., } \\
\text { 2009) }\end{array}$ & $\mathrm{HHI}$ & $\begin{array}{l}0,1 \text { - unproblematic } \\
0,20-\text { critical } \\
\text { (Rosenau-Tornow, et al., } \\
\text { 2009) }\end{array}$ \\
\hline & $\begin{array}{l}\text { 25\% (Erdmann, et al., 2011b) } \\
\text { 10\% (IW Consult, 2009) }\end{array}$ & Top 3 & $\mathrm{n} / \mathrm{a}$ \\
\hline Producer Diversity & $\begin{array}{l}\text { 20\% (Department of Energy, } \\
2010 \text { ) }\end{array}$ & $\begin{array}{l}\text { combined with Country } \\
\text { Concentration }\end{array}$ & $\mathrm{n} / \mathrm{a}$ \\
\hline $\begin{array}{l}\text { Concentration of } \\
\text { Supply \& Value } \\
\text { Chain }\end{array}$ & 16.7\% (Behrendt, et al., 2007) & $\mathrm{n} / \mathrm{a}$ & $\mathrm{n} / \mathrm{a}$ \\
\hline Not considered & \multicolumn{3}{|c|}{$\begin{array}{l}\text { (Frondel, et al., 2006), (U.S. National Research Council, 2008), (Oakdene Hollins, 2008), (Graedel, et } \\
\text { al., 2011a), (European Commission, 2010a), (Thomason, et al., 2010), (Moss, et al., 2011), (Buchert, } \\
\text { et al., 2009), (Duclos, et al., 2008), (Angerer, et al., 2009) }\end{array}$} \\
\hline
\end{tabular}

The studies listed in table 8 measure the company concentration with the Herfindahl-Hirschman Index or with the Top-3-approach, which were already explained in context with the country concentration in chapter 1.4.1.

The relevance of this criterion became clear in history with metallic resources like lithium or vanadium. In case of lithium a price leadership of the Chilean mining company 'Sociedad Química y Minera' (SQM) in the 1990s lead to a ruinous competition. The company SQM was able to suppress other lithium producing companies in the market due to its lower production costs and a high production capacity and gain a dominating position in the market. Because of this, the concentration of raw material producing companies is an important indicator for the evaluation of short-term supply risks. In this context, the question is raised, to which extend the sole contemplation of concentration can be an indicator for supply risk. Here the reason for tensed market situation is bound to the individual conditions for trading the raw material. Metallic resources are traded either at metal trading stock markets or via bilateral trade agreements. It can be assumed that the form of resource trading has a significant impact on the market liquidity and thus on resource oligopolies or monopolies.

Limits for the evaluation are only given by the BGR. For an HHI above 0.2 according to the BGR company concentrations are to be considered as critical (Rosenau-Tornow, et al., 2009). The impact of the company production is weighted with a minimum of $10 \%$ and a maximum of $25 \%$ (IW Consult, 2009) (Erdmann, et al., 2011b). 


\subsubsection{Demand Growth}

Under the category of Demand Growth the expectations for raw material demand developments of five studies can be summarized. With the indicator "Competing Technologies" one study qualitatively rates the impact of fast growing technologies and the impact on the resource availability for the energy sector (Department of Energy, 2010). The criterion represents the strategic relevance of a resource in the application sector and is strongly linked with the substitutability of a resource. The weighting of the indicator was not accessible in the study.

Not the competing, but the future technology demand was assessed in the study of MarscheiderWeidemann. Here the demand for raw materials by future technologies was estimated for the year 2030 and compared with the supply of that material in the year 2006 to display the relative amount of stress on the market by this technology (Angerer, et al., 2009). The results of Angerer, et al., were used by IW Consult as one of seven supply risk indicators. A similar, but qualitative evaluation for demand risk was used by Duclos, et al., as one out of six indicators, while Moss, et al., used the likelihood of rapid global demand growth as one out of four indicators.

Table 9: Studies using the demand growth expectations as a supply risk indicator and its measurement. The table also shows the weight in percent within the aggregation of supply risks evaluation.

\begin{tabular}{|c|c|c|c|}
\hline Criterion & Weight & Measure & Limit \\
\hline $\begin{array}{l}\text { Competing Technology } \\
\text { Demand }\end{array}$ & $\begin{array}{l}10 \% \text { (Department } \\
\text { of Energy, 2011) }\end{array}$ & qualitative & $\mathrm{n} / \mathrm{a}$ \\
\hline $\begin{array}{l}\text { Future Technology } \\
\text { Demand }\end{array}$ & $\begin{array}{l}100 \% \text { (Angerer, et } \\
\text { al., 2009) } \\
20 \% \text { (IW Consult, } \\
2009 \text { ) }\end{array}$ & $\frac{2030 \text { demand from future technologies }}{2006 \text { supply }}$ & $\mathrm{n} / \mathrm{a}$ \\
\hline $\begin{array}{l}\text { Likelihood of rapid global } \\
\text { demand growth }\end{array}$ & $\begin{array}{l}16.7 \% \text { (Duclos, et } \\
\text { al., 2008) } \\
\text { n/a (Moss, et al., } \\
2011 \text { ) }\end{array}$ & qualitative & $\mathrm{n} / \mathrm{a}$ \\
\hline Not considered & \multicolumn{3}{|c|}{$\begin{array}{l}\text { (Frondel, et al., 2006), (U.S. National Research Council, 2008), (Oakdene Hollins, } \\
\text { 2008), (Graedel, et al., 2011a), (European Commission, 2010a), (Thomason, et al., } \\
\text { 2010), (Rosenau-Tornow, et al., 2009), (Buchert, et al., 2009), (Erdmann, et al., } \\
\text { 2011b), (Behrendt, et al., 2007) }\end{array}$} \\
\hline
\end{tabular}

In total, the five studies used the demand growth expectations in an average of $37 \%$. For Angerer, et al., the demand growth was the only indicator, while the Department of Energy only gave it a $10 \%$ weight (Angerer, et al., 2009) (Department of Energy, 2011). None of the studies gave criticality limits for the evaluation of demand growth.

\subsubsection{Recyclability \& Recycling potential}

Recycling as well as recycling potential were used as an indicator for supply risk by the KfW, the European Commission and the NRC study (Erdmann, et al., 2011b) (European Commission, 2010a) (U.S. National Research Council, 2008). In the publication of Yale University, the citerion was used as a variable in the indicator "Depletion Time" (see formula 3, chapter 1.3.3) (Graedel, et al., 2011a). Concerning recycling, a general distinction has to be made between recycling from "new scrap" and from "old scrap". Within the "new scrap" recycling, production waste is returned to the production process. This is the case for example for indium, which is recovered mainly from production rests of 
indium tin oxide (ITO) sputtering. "Old scrap" recycling is the process at the end of a product life cycle. The old scrap recycling is measured by the "end-of-life recycling rate" (EOL-RR), which refers to the whole recycling process. The EOL-RR is calculated by the relation of potentially collectible old material and the actually recycled secondary material (Graedel, et al., 2011c).

When using the recycling quantities or the EOL-RR as an indicator for supply risks, in principle the recycling from "new scrap" should be used as a short-term indicator and from "old scrap" as a long term indicator.

The efficiency of the "new scrap" process can be improved in cast of price increase of the raw material. The additional secondary supply improves the short-term elasticity of the supply. In contrast, the "old scrap" recycling (EOL-RR) is dependant of material, which has to be collected, decomposed, prepared and in the end recycled. Even in case of high price scenarios, the EOL-RR does not necessarily increase within short-term. The supply-demand situation can be toned down by the EOL-RR only long-term.

The difference between technically possible recycling and real collection rates is important. The recycling of gold from mobile phones is technically already possible with an efficiency of 90 to $95 \%$, which theoretically causes a high recycling potential (Hagelücken, 2010). However, this high recycling potential is limited by low collection rates of just $18 \%$ in Germany and $11 \%$ in the USA (Chancerel, 2010). Furthermore, dissipative applications and technically unfavorable metal compounds lead to resources not being able to be recovered.

Up to now, concepts like "Design to recycle" play a marginal role next to performance increase and design (Hagelücken, 2010). Despite these uncertainties "old scrap" and "new scrap" recycling both remain important availability indicators. An example is the recycling of platinum from catalysts for cars, of which over $50 \%$ (EOL-RR) gets recycled. This secondary supply is an important supporting pillar for the supply situation of the precious metal platinum. Table 9 lists the studies using the recycling and the recycling potential as supply risk indicator.

Table 10: Studies using the recycling as an indicator for supply risk and its measurement. Recyclability indicators. The table also shows the weight in percent within the aggregation of supply risks evaluation.

\begin{tabular}{|c|c|c|c|}
\hline Criterion & Weight & Measure & Limit \\
\hline Recycling rate & algorithm & Old scrap / Demand & $\mathrm{n} / \mathrm{a}$ \\
\hline \multirow[t]{7}{*}{ Recyclability } & (European & & \\
\hline & Commission, & & \\
\hline & 2010a), & & \\
\hline & algorithm (U.S. & & \\
\hline & National Research & & \\
\hline & Council, 2008) & & \\
\hline & $\begin{array}{l}\text { 10\% (Erdmann, et } \\
\text { al., 2011b) }\end{array}$ & EOL-RR & $\mathrm{n} / \mathrm{a}$ \\
\hline Not considered & \multicolumn{3}{|c|}{$\begin{array}{l}\text { (Frondel, et al., 2006), (Oakdene Hollins, 2008), (Graedel, et al., 2011a), (Thomason, } \\
\text { et al., 2010), (Department of Energy, 2010), (Moss, et al., 2011), (IW Consult, 2009), } \\
\text { (Rosenau-Tornow, et al., 2009), (Buchert, et al., 2009), (Duclos, et al., 2008), } \\
\text { (Behrendt, et al., 2007), (Angerer, et al., 2009) }\end{array}$} \\
\hline
\end{tabular}

No specific limits for the criticality of recyclability were given in the studies. Only the KfW specifies the weight of the indicator recycling potential of $10 \%$ (Erdmann, et al., 2011b). 


\subsubsection{Substitutability}

The Substitutability of a resource is used as an indicator for supply risk only by three studies: The European Commission, the electronics company General Electric and the Cologne Institute for Economic Research (European Commission, 2010a) (Duclos, et al., 2008) (IW Consult, 2009). In case of General Electric, the substitutability of a resource is evaluated qualitatively by an expert assessment, while the European Commission and the Cologne Institute of Economic Research quantify the criterion as displayed in formula 4 :

$$
\sigma_{i}=\sum_{n=i}^{N} \mathrm{~A}_{\mathrm{is}} \sigma_{\mathrm{is}}
$$

Formula 4: Quantification of the substitutability of a resource. A specifies which share of the raw material is demanded by each application. The value $\sigma$ quantifies the substitutability for each application with 0 (substitutable), 0.5 (substitutably only with high expenses and expenditure) and 1 (not substitutable). After this, with consideration of each application, an average value for substitutability can be achieved (European Commission, 2010a).

The quantification of substitutability with this algorithm turns out to be exceptionally complex, especially for multifunctional raw materials, simply because of the numerous applications. Additionally, the substitutability is not only dependant on the usage of the raw material, but can also vary from one product to the other.

Table 11: Studies using the substitutability as supply risk indicator and its measurement. The table also shows the weight in percent within the aggregation of supply risks evaluation.

\begin{tabular}{llc}
\hline Criterion & Weight & Measure \\
\hline Substitutability & $\begin{array}{l}\text { 10\% (IW Consult, 2009) } \\
\text { n/a (European Commission, 2010a) }\end{array}$ & see Formula 4 \\
\cline { 2 - 3 } & $\begin{array}{ll}16.7 \% \text { (Duclos, et al., 2008) } \\
\text { Not }\end{array}$ & (Frondel, et al., 2006), (U.S. National Research Council, 2008), (Oakdene Hollins, 2008), (Graedel, et al., \\
considered & $\begin{array}{l}\text { 2011a), (Thomason, et al., 2010), (Department of Energy, 2010), (Moss, et al., 2011), (Rosenau-Tornow, } \\
\text { et al., 2009), (Buchert, et al., 2009), (Erdmann, et al., 2011b), (Behrendt, et al., 2007), (Angerer, et al., } \\
\end{array}$ & \\
\hline
\end{tabular}

The reasoning behind using substitutability as a supply risk indicator is the link between substitutability and ability to adapt in case of supply shortages or price increases. Technical possibilities as well as performance losses play a role. It has to be clarified, to which extend any performance losses are going to be accepted by the end user. Nevertheless, the substitutability of raw materials remains to be an important indicator despite the dynamic and complexicity within the evaluation.

No specific limits for criticality of substitutability were given. This supply risk indicator was weighted by the Cologne Institute of Economic Research with $10 \%$, while the the General Electrics approach weighted the indicator with $16.7 \%$ (IW Consult, 2009) (Duclos, et al., 2008). 


\subsubsection{Import Dependence}

Three studies with a nationwide scope implemented the Import Dependence for specific raw materials into their assessments. The study by Thomason, et al., was the only study which used the capability of the United States to provide strategic materials by itself, without relying on imports as an indicator for the supply risk criticality of this material. The NRC study instead calculated the U.S. import dependence of $\mathbf{2 0 0 6}$ for their supply risk evaluation by comparing the net import value with the nation's apparent consumption. Frondel, et al., used the total net import value as the first step to indentify possibly critical raw materials.

Table 12: Studies using the import dependence as supply risk indicator and its measurement. The table also shows the limit for classifying an indicator 'critical' and the weight in percent within the aggregation of supply risks evaluation.

\begin{tabular}{llll}
\hline Criterion & Weight & Measure & Limit \\
\hline U.S. Self-Supply & $\begin{array}{l}100 \% \text { (Thomason, } \\
\text { et al., 2010) }\end{array}$ & U.S. Demand/Self Supply & $\begin{array}{l}>100 \% \text { - critical } \\
\text { (Thomason, et } \\
\text { al., 2010) }\end{array}$ \\
\hline Import Ratio & $\begin{array}{l}\text { algorithm (U.S. } \\
\text { National Research } \\
\text { Council, 2008) }\end{array}$ & Apparent Consumption & n/a \\
\hline Net Import Value & $\begin{array}{l}\text { algorithm (Frondel, } \\
\text { et al., 2006) }\end{array}$ & Net Import Value & $>$ (Frondel, et al., \\
& & & 2006) \\
\hline Not considered & $\begin{array}{l}\text { (Oakdene Hollins, 2008), (Graedel, et al., 2011a), (European Commission, 2010a), } \\
\text { (Department of Energy, 2010), (Moss, et al., 2011), (IW Consult, 2009), (Rosenau- }\end{array}$ \\
& $\begin{array}{l}\text { Tornow, et al., 2009), (Buchert, et al., 2009), (Erdmann, et al., 2011b), (Duclos, et al., } \\
\text { 2008), (Behrendt, et al., 2007), (Angerer, et al., 2009) }\end{array}$ & \\
\hline
\end{tabular}

While the NRC study and Frondel, et al., included their import dependence evaluation into an algorithm for supply risk assessment, Thomason, et al., used the U.S. self-supply as their only indicator. An important limit for both Thomason, et al., as well as Frondel, et al., was the $100 \%$ mark and respectively the $0 \$$ mark, both implying it is impossible for the country to meet domestic demand without imports (Thomason, et al., 2010) (Frondel, et al., 2006).

\subsubsection{Commodity Prices}

In the studies of Duclos and Behrendt, et al., the historic price volatility was used as an indicator for raw material supply risk. In case of Behrendt, et al., the critical level was an increase in commodity prices of $100 \%$ or above between 2001 and 2004. Behrendt, et al, additionally used the price level for criticality assessment: All metals with a price above $\$ 500 / \mathrm{kg}$ were considered to be critical. 
Table 13: Studies using commodity prices as supply risk indicator and its measurement. The table also shows the limit for classifying an indicator 'critical' and the weight in percent within the aggregation of supply risks evaluation.

\begin{tabular}{|c|c|c|c|}
\hline Criterion & Weight & Measure & Limit \\
\hline \multirow[t]{2}{*}{ Historic Price Volatility } & $\begin{array}{l}16.7 \% \text { (Duclos, et } \\
\text { al., 2008) }\end{array}$ & 5-year period maximum volatility & $\mathrm{n} / \mathrm{a}$ \\
\hline & $\begin{array}{l}16.7 \% \text { (Behrendt, et } \\
\text { al., 2007) }\end{array}$ & Price increase 2001 to 2004 & $\begin{array}{l}>100 \% \text { - critical } \\
\text { (Behrendt, et al., } \\
2007 \text { ) }\end{array}$ \\
\hline Price Level & $\begin{array}{l}16.7 \% \text { (Behrendt, et } \\
\text { al., 2007) }\end{array}$ & Price in US-\$/kg & $\begin{array}{l}>500 \$ / \mathrm{kg}- \\
\text { critical } \\
\text { (Behrendt, et al., } \\
2007 \text { ) }\end{array}$ \\
\hline Not considered & \multicolumn{3}{|c|}{$\begin{array}{l}\text { (Frondel, et al., 2006), (U.S. National Research Council, 2008), (Oakdene Hollins, } \\
\text { 2008), (Graedel, et al., 2011a), (European Commission, 2010a), (Thomason, et al., } \\
\text { 2010), (Department of Energy, 2010), (Moss, et al., 2011), (IW Consult, 2009), } \\
\text { (Rosenau-Tornow, et al., 2009), (Buchert, et al., 2009), (Erdmann, et al., 2011b), } \\
\text { (Angerer, et al., 2009) }\end{array}$} \\
\hline
\end{tabular}

Commodity price indicators were always used with a weight of $16.7 \%$, though Behrendt, et al., uses the indicator class twice: Once for price volatility and once for price level. The study of Behrendt, et al., is also the only giving limits for its commodity price indicators: If a price at least doubled in the time span and if the price level was above $500 \$$ per $\mathrm{kg}$ of the raw material it was evaluated to be critical concerning this supply risk indicator (Behrendt, et al., 2007).

\subsubsection{Additional Indicators}

Each additional criterion for supply risk evaluation is only used by individual studies. The investments in exploration, together with the static reach part of the degree of exploration, are defined by the BGR as the exploration budget per ton of the mine production (Rosenau-Tornow, et al., 2009). This quotient is a value for the success quota for exploration. In case of the element of Copper, it can be observed that fewer and fewer of so called "giant deposits" with a value above 10 billion US-dollars are discovered. Because of this, the degree of exploration will increase in future (Evans, 2006). The measurement of the exploration costs is an indicator for a supply shortage of the resource. For the calculation of the degree of exploration, periods of 10 to 15 years have to be taken into account, starting with the exploration until the factual production. In this time, long-term economical effects like inflation can have severe impact. In case of by-product dependencies the question about which resource gets which exploration costs has to be clarified.

The development of production costs for extraction was also used by the BGR as an indicator for supply risk. From the calculation of costs, which incur at the processing, important information can be derived for addressing short-term as well as long-term trends for resource availability. Nonetheless, this data is mostly confidential in the mining and processing industry and is only partially available and accessible.

Another indicator used in the publication of the BGR is the stock keeping of resources (RosenauTornow, et al., 2009). This can have a strong influence on the supply and demand elasticity of resources. In case of platinum for example during the last 10 years up to $10 \%$ of the annual supply 
was secured by stockpiling. The BGR study also assessed the current market balance, which measures differences in production and consumption with consideration of the change in stocks in tonnes. Negative market balances below -100 tonnes are considered as problematic by the BGR. The mine or refinery capacity utilisation in percent is the ratio between real production and mine or refinery capacity and was also used by the BGR as a supply risk indicator. Here capacity utilisations above 90 $\%$ were evaluated as problematic. Mine or refinery capacity only evaluates current production capacities, the indicator future market capacity in contrast rates the change until a certain year by including the additional annual production capacity and comparing with necessary future mine production. On the financial side of mining operations, the BGR also rates the investment in mining in units of US-dollars spent per tonne mine production. For all these BGR-specific indicators, only partial aggregations apply. Their paper displays supply risk results from ten indicators in a spider chart of five different subvalues. It is therefore not possible to give weighting values for those single-use indicators used by BGR (Rosenau-Tornow, et al., 2009).

An indicator called climate change vulnerability was used by the study of Oakdene Hollins. It measures the proximity of production countries to climate change hot spots as defined by the German Advisory Council on Climate Change. The climate change vulnerability accounted for $25 \%$ of the total supply risk evaluation in the study by Oakdene Hollins (Oakdene Hollins, 2008). Buchert, et al., used a temporary scarcity, which is a measure of the time lag between production and demand, without giving detailed information on how this time lag is calculated. The temporary scarcity has been weighted with $25 \%$ in the supply risk assessment (Buchert, et al., 2009).

IW Consult additionally used an indicator called 'risk of strategic use'. For this indicator an expert group has evalued the raw materials for their risk of being used as a political or strategic instrument. Taxes, export restrictions and finishing bans used by the production countries were considered for this indicator. It was weighted in IW Consult's rating with $20 \%$ (IW Consult, 2009). The abundance in earth's crust was used by Duclos, et al., as one out of six supply risk indicators (Duclos, et al., 2008). They preferred this indicator over the widely used depletion time approach which often considers reserve or reserve base volumina. This way, frequent raw materials that are rarely economically accessible like rare earths would profit from the approach Duclos, et al., chose due to the usage of this abundance indicator.

\subsection{Data base of Supply Risk indicators}

Now it shall be discussed, how the data base of the indicators is evaluated. For this the resource indium was chosen, because it was used the most within all selected studies.

For the country concentration of production capacities the used data base of the studies is limited to the U.S. Geological Survey (USGS). The USGS is the worldwide largest geological institute and offers records for production, demand, price, stockpiling and recycling levels for mineralic resources. According to current data, in year 2010 indium was processed to $52 \%$ in China, 14 \% in South Korea and $12 \%$ in Japan. However, no further information about the extraction quantities and the country concentration of the raw material is given. One reason for this is that indium is a typical by-product of zinc extraction, resulting in a lack of explicit data for the extraction of this trace element. Consequentially, the Scientific Advisory Board of the European Commission and Oakdene Hollins rate the country concentration solely on the basis of the concentration of processing capacities. The concentration was rated with 2 (critical) on a scale from 0 to 3 (Moss, et al., 2011) (Oakdene Hollins, 2008). For other studies the specific rating of this indicator remains unclear. 
The country risk for processing capacities was rated by Oakdene Hollins as critical with a score of 0.48 (of 1) (Oakdene Hollins, 2008). The study of KfW estimates the political risk with 0.08 (of 1) and thus as uncritical (Erdmann, et al., 2011b). This is mainly because of the KfW using the general index, displaying the average of all WGI indices, while Oakdene Hollins uses only the subindicator 'political stability'.

According to the USGS, another source for Indium is the by-production from copper, lead, tin and precious metals (USGS, 2012). Because of this high dependency on by-production, $\mathrm{KfW}$ and UNEP rate this indicator as a critical (Erdmann, et al., 2011b) (Buchert, et al., 2009). The uncertainties emerging from this by-product dependency lead to the USGS not listing figures for indium reserves since year 2007. Within the study of $\mathrm{KfW}$, the static reach of zinc reserves is used instead and the result of 17 years is rated as uncritical (Erdmann, et al., 2011b). Without naming sources, Oakdene Hollins estimates that the indium demand will have exceeded the reserve base by the year 2050, rating it as critical (Oakdene Hollins, 2008).

Most of the selected studies used the database Asian Metals, the company Indium Corporation or the USGS as the citation of the indicator concentration of raw material production companies in case of indium. As Asian Metals is a subscription database, it was not accessible to check the sources due to financial reasons. The Indium Corporation does not give public information about raw material producing companies, which is why no information could be gathered in this case. The USGS in contrast estimates theoretical production capacities of single companies, but no actual production values were given (Tolcin, 2008). Concrete data thus could not be found regarding company concentration, and transparent evaluation was not possible.

The evaluation of the substitutability of indium was only made by the Fraunhofer ISI and is limited to the expert assessment as quantified in the study of the European Union (European Commission, 2010a). In this study the substitutability index of indium is rated with a value of 0.9 (of 1 ) and thus as critical.

Information about the recyclability of indium was extracted from the study of the European Union (European Commission, 2010a). In that study the EOL-recycling rate is listed as $0.03 \%$. Based on this specification, the $\mathrm{KfW}$ estimates the recyclability with respect to the long-term availability of resources with 0.72 (of 1) and thus as critical (Erdmann, et al., 2011b). Next to the "old scrap" recycling, the "new scrap" recycling also has an enormous influence on the availability of the resource Indium. This secondary source of raw material was not used in any of the selected studies. The USGS states that every year about 400 tons of indium are getting recycled during the production process of indium tin oxide (ITO), which meets around $50 \%$ of today's processing capacity (Tolcin, 2007). Thus it can be recommended to include "new scrap" recycling for future criticality assessments.

Data or the rating for additional indicators like competing technology demand, degree of exploration, production costs and technical development for extraction of stockpiling could not be accessed from the studies.

\section{Summary and outlook}

This research paper is focusing on a relatively new research area called Raw Material Criticality. The scope of criticality assessement methods is to analyze driving factors, which makes a raw material critical from an economic, ecological, social or even ethical perspective. For the target value supply 
risk, it could be shown which study is applying which set of criteria and how these criteria had been quantified and finally rated. Moreover it has been discussed to which extend the indicators do have a significant forecast quality to long and short term supply risks. In this context Indium was analyzed in detail. Indium was one of the two materials used most frequently in the selected studies. It has been shown that especially production and reserve capacity numbers as well as other basic facts are uncertain for by-products like indium.

These results show that in principle three research questions can be identified for the field of Supply Risk assessment: Which indicators are meaningful for supply risk assessment? How do they have to be aggregated to get a meaningful evaluation? And which uncertainties are implied within each assessment? This need for further reseach concerns the selection of indicators, their aggregation as well as the uncertainties occuring at the supply risk evaluation.

\section{Selection of Indicators}

A closer look at the selection of the indicators shows that each study uses very different and varied indicators for the supply risk assessment. In the studies, no reason was given why single criterions were used, while the others were not considered. In the analysis of the indicator it got obvious that the selection of indicators is highly dependent on the functionality of the relevant elements in its end-use products. For example, lithium can be mined with a battery grade or with a lower standard for lubricants. Each end use product is dependent on a supply chain with different country concentrations during the production process as well as different substitiution and recycling possibilities on the demand side. We therefore want to encourage further criticality studies to put a stronger focus on the specific element and its functionalities.

\section{Aggregation of Supply Risk Indicators}

The aggregation of indicators in the studies was made almost exclusively by calculating the weighted average. However, the weighting of single indicators is handled very differently and empiric evidence about the influence of the indicators on supply risks is missing. Whether supply risks are additive, selective or multiplicative, the studies do not elaborate, though most of the time the assumption of additivity is made by using average or weighted average aggregation. Furthermore, it has to be said that limits for the evaluation of single indicators are rarely given or even fixed without further foundation.

\section{Uncertainties of Supply Risk Indicators}

Another important point is the uncertainty of the supply risk assessment. Within the assessment, among others, dynamic indicators like the substitutability of raw materials were used. Their forecast is only possible with vast uncertainties. Additionally, information deficits for the production quantities and concentrations occur. These uncertainties should be considered in future studies to raise their meaningfulness.

As these research questions already indicate, up to now there is only a limited understanding of price and availability influencing factors. The criticality assessment methods analyzed in this study can be seen as a starting point for a better understanding of raw material supply and demand. This work already shows that on the demand and supply side there is currently only intransparent and limited data available. It therefore will be the biggest challenge to get a comprehensive database of all raw 
material supply chain levels from the mining, to the manufacturing of products and the end of life phase with dissipation and recycling.

\section{Acknowledgments}

The authors wish to thank Julia Grimm for her valuable help in data preparation and Lars Wietschel for his assistance in proofreading.

\section{References}

Achzet, B., 2009. Strategische Rohstoffplanung zu elektrischen Antriebstechnologien im Automobilbau, s.l.: s.n.

Achzet, B., 2012. Empiritsche Analyse von preis- und verfügbarkeitsbeeinflussenden Indikatoren unter Berücksichtigung der Kritikalität von Rohstoffen. Augsburg: s.n.

Angerer, G. et al., 2009. Raw Materials for Emerging Technologies, Stuttgart: Frauenhofer IRB Verlag.

Angerer, G., Mohring, A., Marscheider-Weidemann, F. \& Wietschel, M., 2010. Kupfer für Zukunftstechnologien, s.l.: s.n.

Asian Metals, 2011. [Online] Available at: http://www.asianmetal.com [Accessed 2812 2011].

Behrendt, S. et al., 2007. Maßnahmen und Konzepte zur Lösung des Problems konfliktverschärfender Rohstoffausbeutung am Beispiel Coltan, Berlin: Umweltbundesamt.

Bleymüller, J., Gehlert, G. \& Gülicher, H., 1996. Statistik für Wirtschaftswissenschaftler. München: WiSt-Studienkurs.

Buchert, M., Schüler, D. \& Bleher, D., 2009. Critical Metals for Future Sustainable Technologies and their Recycling Potential, Berlin: United Nations Environment Programme.

Chancerel, P., 2010. Substance Flow Analysis of the Recycling of Small Waste Electrical and Electronic Equipment - An Assessment of the Recovery of Gold and Palladium, Berlin: Institut für Technischen Umweltschutz.

Department of Energy, 2010. Critical Mineral Strategy, Washington: U.S. Department of Energy.

Department of Energy, 2011. Critical Mineral Strategy. Washington: U.S. Department of Energy.

Duclos, S. J., Otto, J. P. \& Konitzer, D. G., 2008. Design in an Era of Constrained Resources: as Global Competition for Materials strains the Supply Chain, Companies must know where a Shortage can hurt and then plan around it.. Mechanical Engineering magazine.

Erdmann, L., Behrendt, S. \& Feil, M., 2011b. Kritische Rohstoffe für Deutschland, Berlin: KfW Bankengruppe.

Erdmann, L. \& Graedel, T., 2011a. Criticality of Non-Fuel Minerals: A review of major Approaches and Analyses. Environmental Science \& Technology, Issue 7260-7630.

Eurasia Group, 2012. [Online] Available at: http://eurasiagroup.net/research-capabilities /comparative-analytics [Accessed 03 2012].

European Commission, 2010a. Critical Raw Materials for the EU, Brüssel: European Commission.

European Commission, 2010b. Annex V to the Report of the Ad-hoc Working Group on Defining Critical Raw Materials, Brüssel: Ad-hoc Working Group.

Evans, A., 2006. Introduction to Mineral Exploration. Victoria, Australia: Blackwell Publishing.

Frondel, M., Angerer, G. \& Buchholz, P., 2006. Trends der Angebots- und Nachfragesituation bei mineralischen Rohstoffen, Berlin: BMWi. 
Graedel, T. et al., 2011c. What Do We Know About Metal Recycling Rates?. Journal of Industrial Ecology, 3(355-366).

Graedel, T. et al., 2011b. Recycling Rates - A Status Report, s.l.: United Nations Environment Programme (UNEP).

Graedel, T. et al., 2011a. Methodology of Criticality Dertermination. Environmental Science \& Technology.

Hagelücken, C., 2010. Wir brauchen eine globale Recyclingwirtschaft - mit völlig neuen Ansätzen.

[Online] Available at: http://www.nachhaltigwirtschaften.at/nw pdf/events/20101011 rohstoffversorgung christian hagelueken.pdf

Hagelücken, C. \& Meskers, C., 2010. Complex Life Cycles of Precious and Special Metals, Cambridge: Strüngmann Forum Report.

IW Consult, 2009. Rohstoffsituation Bayern: Keine Zukunft ohne Rohstoffe, München: vbw.

Kaufmann, D., Kraay, A. \& Matruzzi, M., 2012. http://info.worldbank.org. [Online] Available at: http://info.worldbank.org/governance/wgi/index.asp [Accessed 02 2012].

Kristof, K. \& Hennicke, P., 2010. Endbericht des Projekts "Materialeffizienz und Ressourcenforschung" (MaRess), Wuppertal: Wuppertal Institut für Klima, Umwelt, Energie GmbH.

Langhammer, D., 2010. An Empirical Analysis of Structrual Forces in Refractory Metal Markets. Augsburg: Dissertation in Kooperation mit Mc Kinsey.

Moss, R. et al., 2011. Critical Metals in Strategic Energy Technologies, Luxenburg: European Commossion.

Oakdene Hollins, 2008. Material Security - Ensuring Resource Availability for the UK Economy, Chester: C-Tech innovations.

Raw Materials Group, 2011. Raw Materials Group Database. s.I.:s.n.

Rosenau-Tornow, D., Buchholz, P., Riemann, A. \& Wagner, M., 2009. Assessing the Long-Term Supply Risks for Raw Materials - A Combined Evaluation of Past and Future Trends. Resources Policy, Issue 161-175.

Roskill Information Servies, 2012. [Online].

Sectretary of Defense, 2011. Operations under the Strategic and Critical Materials Stockpiling Act during the Period October 2009 through September 2010. [Online] Available at: https://www.dnsc.dla.mil/Uploads/Materials/dladnsc2 9-13-2011 15-9 40 FY10\%200ps\%20Report\%20-\%2005-06-2011.pdf [Accessed 02 2012].

Sievers, H., Buchholz, P. \& Huy, D., 2011. Evaluating Supply Risks for Mineral Raw Materials, Hannover: http://www.polinares.eu/.

Thomason, S. et al., 2010. From National Defense Stockpile (NDS) to Strategic Materials Security Program (SMSP): Evidence and Analytic Support, Washington: Institue for Defense Analysis.

Tilton, J. \& Lagos, G., 2007. Assessing the Long-Run Availability of Copper. Resources Policy.

Tolcin, A. C., 2007. Indium Fact Sheet 2007. [Online] Available at: $\underline{\text { http://minerals.usgs.gov/minerals }}$ /pubs/commodity/indium/myb1-2007-indiu.pdf [Accessed 04 2012].

Tolcin, A. C., 2008. Indium Fact Sheet 2008. [Online] Available at: http://minerals.usgs.gov/minerals /pubs/commodity/indium/myb1-2008-indiu.pdf [Accessed 04 2012].

U.S. Department of Justice and the Federal Trade Commission, 2010. Horizontal Merger Guidelines. [Online] Available at: http://www.justice.gov/atr/public/guidelines/hmg-2010.html [Accessed 12 2011]. 
U.S. National Research Council, 2008. Minerals, Critical Minerals, and the U.S. Economy. Washington D.C.: National Academic Sciences.

United Nations Development Programme, n.d. Human Development Reports. [Online] Available at: http://hdr.undp.org/en/contacts/about/advisory/ [Accessed 03 2012].

USGS, 2006. U.S. Geological Survey Bulletin 1450-A. [Online] Available at: http://pubs.usgs.gov/bul/b1450b/b1450.htm [Accessed 2312 2011].

USGS, 2011. U.S. Geological Survey. [Online] Available at: http://minerals.usgs.gov/ds/2005/140/

USGS, 2012. U.S. Geological Survey. [Online] Available at: http://minerals.usgs.gov/minerals /pubs/commodity/ [Accessed 04 2012].

USGS, 2013. U.S. Geological Survey. [Online] Available at: http://minerals.usgs.gov /minerals/pubs /mcs/2013/mcsapp2013.pdf

Wadia, C., Alivisatos, A. P. \& Kammen, D. M., 2009. Materials Availability Expands the Opportunity for Large-Scale Photovoltaics Deployment. Environmental Science Technology, Issue 6.

Zepf, V. et al., 2011. Materials critical to the energy industry, s.I.: s.n. 